\title{
Investigating English Language Speaking Anxiety among Malaysian Undergraduate Learners
}

\author{
Nuraqilah Nadjwa Miskam ${ }^{1} \&$ Aminabibi Saidalvi ${ }^{2}$ \\ ${ }^{1}$ School of Education, Faculty of Social Sciences and Humanities, Universiti Teknologi Malaysia, Johor, Malaysia \\ ${ }^{2}$ Language Academy, Faculty of Social Sciences and Humanities Universiti Teknologi Malaysia, Johor, Malaysia \\ Correspondence: Miskam, Nuraqilah Nadjwa, School of Education, Faculty of Social Sciences and Humanities, \\ Universiti Teknologi Malaysia, Johor, Malaysia. E-mail: aqilahnadjwa@gmail.com
}

Received: November 6, 2018

Accepted: December 1, 2018

Online Published: December 29, 2018

doi:10.5539/ass.v15n1p1

URL: https://doi.org/10.5539/ass.v15n1p1

\begin{abstract}
Malaysian graduates have a serious lacking in speaking English and this situation has raised an alarming concern in securing employment in the future. Many Malaysian graduates perceive speaking in a foreign language as an intimidating task. This is due to the existence of foreign language anxiety that serves as a hindrance for the undergraduate learners to speak in a foreign language. This study aims to determine the level of speaking anxiety among Malaysian undergraduate learners. The Foreign Language Speaking Anxiety Scale (FLSAS) by (Balemir, 2009; Huang, 2004) was adapted and administered to measure the level of students' speaking anxiety. 42 undergraduate learners from one of the public universities in Malaysia have been selected to participate in this study. Data collected through questionnaire was analysed using statistical analysis. The result from the study showed that undergraduates have English language speaking anxiety to a certain level. The findings of this study will assist both undergraduates and educators to be more aware of the level of English language speaking anxiety in order to overcome this perturbing issue.
\end{abstract}

Keywords: English language, speaking, anxiety, speaking anxiety, undergraduates, FLSAS

\section{Introduction}

Second language or foreign language speaking anxiety has sparked a lot of attention in the recent years. Numerous studies have been conducted to investigate the level of speaking anxiety experienced by students (Subasi, 2010; Mak, 2011; Kayaoglu \& Saglamel, 2013). Speaking has been cited as the most anxiety-inducing skill in language learning and it is the most conspicuous source of anxiety in language classroom (Ozturk \& Gurbuz, 2013). The fact that most Malaysian graduates still face difficulty in producing sentences in English and speaking in that language is puzzling, despite the fact that they have been exposed to this language since kindergarten. The case where graduates faced problem in conversing in English at job interviews might lead to the increasing number of unemployed graduates in our nation (Mehar Singh \& Chuah, 2012).

\subsection{Background}

The importance of mastering second language has been well acknowledged by most people especially students in the past few years. As language plays a prominent part in human life, it is crucial for one to learn and acquire language for effective daily interaction and communication. Many have started to recognize the benefits of mastering a second language.

Thousands of schools around the world offer English as a learning subject. In Malaysia, the Ministry of Education has taken various measures to introduce English language as early as kindergarten till varsity (Lin, 2013). Besides, English has been designated as a compulsory subject to pass at all level of education, which highlights the importance of mastering the language.

English is pivotal for the future generation hence, lots of new and improved efforts have been taken by the Ministry of Education. The government re-introduced the teaching and learning of Science and Mathematics in English back in 2002 and later, the introduction of MBMMBI (Upholding the Malay Language and Strengthening Command of English) in 2009 to improve students' English proficiency as the second language in Malaysia. Students will be able to explore vast knowledge areas when they are competent in English language (Rokiah @ Rozita Ahmad et al., 2012). 
In spite of all the above efforts, graduates still face difficulty not only in producing sentences in English but also using the language for communication. Most potential employers prefer graduates with good English language proficiency skills as it is important for employability (Mehar Singh \& Chuah, 2012) without which will increase unemployment in the country. So, a shift in the Education Blueprint was done to ensure graduates are equipped with fluent communication skills upon graduating (Malaysian Educational Blueprint, 2011).

There are several other factors that lead to poor communication skills among graduates and one of them is anxiety. Language anxiety has a prominent influence on language learning. Brown (1994) asserted that learning a second language can be a complex process and causing these learners to have anxiety. Horwitz et al. (1986) asserted that speaking is one of the most anxiety-provoking situations for most learners. Since speaking covers many processes of language learning such as word pronunciation, word recognition, meaning and grammar rules, it can be overwhelming for learners to master all of these processes (Fielding et al., 2007).

There is an urgent need to address the issue of anxiety as it can lead to undeveloped proficiency and affect the performance and achievement in language learning (Brown, 1987). This study investigated the level of English language speaking anxiety and the dominant factor that contributes to English language speaking anxiety among Malaysian undergraduates.

\subsection{English Language Speaking Anxiety}

Second language or foreign language speaking anxiety has sparked a lot of interest in the literature (Subasi, 2010; Mak, 2011). Speaking has been highlighted as the most anxiety-provoking skill and it is the most prominent source of anxiety in language classroom (Saltan, 2003; Ozturk \& Gurbuz, 2013). According to Balemir (2209), speaking anxiety can be defined as the fear of using the language orally.

Suleimenova (2013) noted that the concern over communication competence among second or foreign language learners in the recent years may trigger a high level of speaking anxiety. In his study, the foreign language learners stated that they feel stressful, nervous and anxious while learning to speak using the target language and said to have 'mental block' against language learning. Similarly, Karatas et al. (2016) supported Suleimenova (2013) notion in which students in language classroom have to perform orally in front of their peers and they need to participate in group discussions. When communication competence is the center focus in language classroom, learners will feel intimidated to perform such task and perceived it negatively.

Writing and speaking are considered as output skills in language learning. However, unlike writing, the grammatical, lexical and discourse pattern in speaking differs in various ways. Speaking is both a productive as well as an interactive skill (Carter \& Nunan, 2002). Therefore, many students fumbled when they are asked to perform oral communication task as speaking requires more complex skills than other language tasks.

\subsection{Level of Speaking Anxiety}

The literature has indicated studies that focused on the level of English language speaking anxiety in relation with gender, motivation, proficiency and the time the learners' start to learn English (Dalkilic, 2001; Huang, 2004; Wilson, 2006; Batumlu \& Erden, 2007).

Huang (2004) investigated the relationship between motivation for learning and anxiety for speaking foreign languages in the Taiwanese context. The study aimed to investigate the relationship between anxiety and gender in foreign languages, the time of learning English and the willingness to study after school. Foreign Language Speaking Anxiety Scale (FLCAS) by Horwitz et al. (1986) was distributed to 502 EFL learners in a university in Taiwan. The results showed that the female participants are more anxious than the male. Students who have started learning English in kindergarten are less anxious than those who have started learning English in secondary school. In addition, students who study English after class were less anxious than those who were not

Karatas et al. (2016) explored the relationship between students' foreign language speaking with gender, level of language, English preparatory training and the type of secondary school from which they graduated. The respondents include 320 males and 168 female English preparatory students at Istanbul Technical University. Foreign Language Classroom Anxiety Scale by Horwitz et al. (1986) adapted by Saltan (2003) was used. The result showed that, in terms of gender, their findings are parallel with Huang (2004) and Ozturk and Gurbuz (2013) that female respondents have higher anxiety level than male respondents. In terms of English preparatory training, students who received English preparatory training has lower anxiety than those who did not received any. Students' level of language and the kind of high school they graduated from did not have any effect on their speaking anxiety.

Llinas and Garau (2009) examined the impact of anxiety in foreign languages on Spanish students at three different levels of proficiency. 134 students taking Spanish courses at a university in USA were selected as 
participants and the Foreign Language Classroom Anxiety Scale (Horwitz et al., 1986) was administered. The results showed that the participants at the advanced level were the most anxious while the participants at the beginner level were the least. Their final grades were also compared to analyze how anxiety of languages affects their achievement in the course. It showed that advanced students are the most worried and have a higher grade than the other students. The researcher inferred that the advanced level participants are aware of their purpose in learning the foreign language which is to prepare themselves for employability. Therefore, they feel more pressure and anxious than learners who take the language course to pass the requirement.

Llinas' and Garau's (2009) findings, however, contradict with Hismanoglu's (2013) findings. Hismanoglu (2013) investigated English language teacher candidates' language learning anxiety in Turkey. The findings showed that learners in the advanced level are less anxious than learners at the beginner level. Skehan (1989) asserted that students at an advanced level of study enjoy "a wider repertoire of behaviors" which aid them in overcoming their anxiety in learning a language (p. 116).

\subsection{Factors of Speaking Anxiety}

Horwitz, Horwitz and Cope (1986) who pioneered the term foreign language anxiety as a specific syndrome have stem three other form of anxieties: 1) communication apprehension 2) fear of negative evaluation 3) test anxiety. The description of these three aspects in foreign language anxiety will lay the basis for foreign language anxiety concept thus giving insights to further comprehend the concept.

Communication apprehension can be defined as the worry about oral communication (Horwitz et al., 1991). McCroskey (1997) defined communication apprehension as “... an individual's level of fear or anxiety associated with either real or anticipated communication with another person" (p. 78). The personality traits of individuals such as shyness, quietness or reluctance are among the causes of an apprehension of communication. McCroskey and Anderson (1976) stated that communication apprehension has been depicted to have harmful impact on the performance of learners in communication-based classrooms, such as the foreign language teaching. Therefore, communication apprehension appears to have such a weakening effect on language learners and can negatively contribute to language anxiety.

The second type of anxiety according to Horwitz et al. (1986) is the fear of negative evaluation. Fear of negative evaluation according to Horwitz et al. (1986) is an "apprehension about other's evaluation, avoidance of evaluative situations and the expectation that others would evaluate oneself negatively" (p. 128). Using a foreign or second language is regard as a case of being evaluated by some learners. They are concerned about portraying improper social impression about themselves especially if they are aware about their lack of necessary linguistics competence to produce the language (Aydin, 2001).

The third anxiety proposed by Horwitz et al. (1991) is test anxiety which refers to "type of performance anxiety stemming from fear of failure" (p. 127). Test anxiety has four phases: test anticipation, test preparation, test-taking stage and test reaction (Covington, 1985). In the test anticipation phase, students begin to evaluate their own preparation, their prior knowledge, the test difficulty level and predict their possible performance (Balemir, 2009). Students will start to feel anxious when they know they are going to fail a test (Aydin, 2001). In the second phase which is test preparation, learners will start to prepare for the test, perceive the effectiveness and their test preparation. They put impracticable demands on themselves and they feel that any grade less than excellent is unacceptable for anxious learners even if it is good enough for others (Namsang, 2011). The third phase of test anxiety is test taking phase where the learners feel repressed and frustrated caused by anxiety. In the last stage, their negative perceptions of taking a test is usually recognized (Aydin, 2001).

\section{Method}

This study employed a survey research design. It provides quantitative or numeric description of trends, attitudes or opinions of a population studying a sample of that population (Creswell, 2014). The participants were 42 third-year undergraduates taking one of the compulsory English subjects for undergraduates, which is English for Professional purpose subject. These participants are from Universiti Teknologi Malaysia. The third year undergraduates are selected because they have done a lot of oral presentations throughout their three years of study in the university. The subject that they were taking focused on oral communication skills among the undergraduate hence, making them the suitable participants for this study. Since English is the medium of instruction in the university, these students must deliver their presentation in English language. The participants were chosen based on random sampling method as to avoid biasness and to ensure good representative of the population (Alvi, 2016).

This study utilized a set of questionnaire adapted from Balemir (2009) on Foreign Language Speaking Anxiety 
Scale (FLSAS) as instrument for data collection, which was also utilized by Nur Afiqah Ab. Latif (2015) and Hismanoglu (2013). Researchers have proven that FLSAS is a relevant instrument to be used to determine the level of English language speaking anxiety. The Cronbach's Alpha value of all the 28 items in this questionnaire is .822 which suggests that the items have relatively high internal consistency (Tercan \& Dikilitas, 2015). This instrument is used to collect the data related to the level of English language speaking anxiety and the dominant factor that contribute to the English language speaking anxiety among Malaysian undergraduates based on the three factors that have been identified by Horwitz, Horwitz and Cope (1986) which are communication apprehension, fear of negative evaluation and test anxiety.

This study is conducted by distributing and recollecting the questionnaire to the selected participants. 45 questionnaires were distributed and 42 were returned. The data obtained from the questionnaire were analysed using statistical analysis SPSS version 23.0 and presented in the form of descriptive statistics together with percentage and mean.

\section{Results}

\subsection{Level of English Language Speaking Anxiety}

The FLSAS used to measure the level of English language speaking anxiety among Malaysian undergraduates contained 28 items. FLSAS used a 5-point Likert scale in which it ranged from one 'strongly disagree' to five 'strongly agree'. The items in FLSAS that are negatively worded were scored reversely.

Table 1 below presents the level of English language speaking anxiety among Malaysian undergraduates. It can be noted that 32 participants (76\%) have moderate level of English language speaking anxiety. 5 participants (12\%) have high level of English language speaking anxiety and another 5 participants (12\%) have low level of English language speaking anxiety.

Table 1. Level of English language speaking anxiety among Malaysian undergraduates

\begin{tabular}{cccc}
\hline Total FLSAS & Anxiety Level & Frequency & Percentage \\
\hline $98-140$ & High & 5 & $12 \%$ \\
$70-97$ & Moderate & 32 & $76 \%$ \\
$28-69$ & Low & 5 & $12 \%$ \\
\hline
\end{tabular}

Table 2 below illustrates the factors of English language speaking anxiety for learners with high level of speaking anxiety.

Table 2. Factors of English language speaking anxiety for learners with high level of speaking anxiety

\begin{tabular}{lll}
\hline Factor of Speaking Anxiety & Items & Mean \\
\hline Communication apprehension & $1,3,7,8,11,14,17,20,24,25,28$ & 3.83 \\
Fear of negative evaluation & $2,4,6,9,10,13,15,18,22,23$ & 3.62 \\
Test anxiety & $5,12,16,19,21,26,27$ & 3.62 \\
\hline
\end{tabular}

Based on the table, it can be seen that communication apprehension has the highest mean $(\mathrm{M}=3.83)$ followed by fear of negative evaluation ( $M=3.62)$ and test anxiety $(M=3.62)$. Therefore, communication apprehension is the dominant factor that contribute to English language speaking anxiety among Malaysian undergraduates for high anxiety learners.

Table 3 below presents the factors that contribute to English language speaking anxiety for learners with moderate level of speaking anxiety.

Table 3. Factors of English language speaking anxiety for learners with moderate level of speaking anxiety

\begin{tabular}{lll}
\hline Factor of Speaking Anxiety & Item & Mean \\
\hline Communication apprehension & $1,3,7,8,11,14,17,20,24,25,28$ & 3.20 \\
Fear of negative evaluation & $2,4,6,9,10,13,15,18,22,23$ & 3.03 \\
Test anxiety & $5,12,16,19,21,26,27$ & 2.90
\end{tabular}

The result from Table 3 shows that communication apprehension has the highest mean $(M=3.20)$ compared to fear of negative evaluation $(M=3.03)$ and test anxiety $(M=2.90)$. Hence, the dominant factor that contribute to 
English language speaking anxiety for moderate anxiety learners is communication apprehension, which is similar to high anxiety learners.

Table 4 below shows the contributing factors of English language speaking anxiety for learners with low level of speaking anxiety.

Table 4. Factors of English language speaking anxiety for learners with low level of speaking anxiety

\begin{tabular}{lll}
\hline Factor of Speaking Anxiety & Item & Mean \\
\hline Communication apprehension & $1,3,7,8,11,14,17,20,24,25,28$ & 2.34 \\
Fear of negative evaluation & $2,4,6,9,10,13,15,18,22,23$ & 2.16 \\
Test anxiety & $5,12,16,19,21,26,27$ & 2.42 \\
\hline
\end{tabular}

As shown is Table 4, the factor with the highest mean is test anxiety $(\mathrm{M}=2.42)$, followed by communication apprehension $(M=2.34)$ and fear of negative evaluation $(M=2.16)$. It is apparent that test anxiety is the dominant contributory factor of English language speaking anxiety for low anxiety learners.

\section{Discussion}

The first question in this study was to investigate the level of English language speaking anxiety among Malaysian undergraduate learners. The result from FLCAS indicates that majority of the participants (76\%) have moderate level of English language speaking anxiety which is similar to the findings by Balemir (2009), Abdullah and Abdul Rahman (2010) and Chan, Abdullah and Yusuf (2010). However, even with moderate level of English language speaking anxiety, it is still worrying as this level of anxiety can be debilitative to the learners' performance. It can affect the students' ability to express their thoughts and opinions in English (Cagatay, 2015) and their readiness to communicate (Wu \& Lin, 2014).

The second question in this study was to determine the dominant factor that contributes to English language speaking anxiety among Malaysian undergraduates. This study found that for high and moderate level of speaking anxiety, the dominant factor for English language speaking anxiety among these learners is communication apprehension. The students will start to feel self-conscious when they are asked to speak English in front of their peers. This finding is in line with a study done by McCroskey (1992) which indicated that majority of learners experienced communication apprehension when they to speak in a formal setting in front of a group people, for example in a classroom. Besides, based on FLCAS, when learners with moderate and high level of speaking anxiety cannot express their thoughts and opinions effectively while speaking English, they will start to get anxious, which corroborates the finding by Suleimenova (2013). His study found anxiety tampered with the capability of the learners to focus on what is said in the target language and even if they had ideas, anxiety has taken over the situation. It means anxiety can hamper their speech performance and leads to communication apprehension.

However, for learners with low level of speaking anxiety, the dominant contributory factor of English language speaking anxiety is test anxiety. A study done by Llinas and Garau (2009) showed that high proficiency students are more aware of their purpose in learning a foreign language. This explains that low anxiety learners are anxious about their oral test conducted in English language as they need to pass the requirement that is highly demanded for employability. Daikilic's (2001) and Huang's (2004) studies also depicted the same result that learners did experienced test anxiety in speaking class. The fear of exams creates an intimidating atmosphere for the learners (Kayaoglu \& Saglamel, 2013) and it can impede learners' performance (Horwitz et al., 1986).

\section{Conclusion}

The present study was designed to determine the level of English language speaking anxiety and the dominant factor that contributes to English language speaking anxiety among Malaysian undergraduate learners. Based on the findings, it suggests that majority of these undergraduates have moderate level of speaking anxiety. The dominant factors that contribute to this issue is communication apprehension for high and moderate anxiety learners while for low anxiety learners, it is test anxiety. These negative factors have the ability to influence the learners' effort to learn English and impede their learning performance and causing them to not be able to speak English.

It is believed that English language speaking anxiety could obstruct the performance of learners in speaking the target language. The findings from this research can serve as a guidance for both instructors and learners to further improve their speaking skill and to tackle the issue of speaking anxiety in English classroom. Greater efforts are needed to ensure that instructors inculcate a stress-free and supportive classroom environment. Being 
sensitive to learners' anxiety and helping them in overcoming those anxiety will give a tremendous impact on their learning performance. The instructor may consider having more group work to lower the level of anxiety experienced by learners. Oral test can be done in a less intimidating way by giving some options on the topics for learners to choose and treat it as practice to encourage learners to speak rather than a requirement for the students to pass. Further research should be undertaken in this field to explore other factors that may be related to English language speaking anxiety and the strategies that can be used to overcome this issue.

\section{References}

Alvi, M. H. (2016). A Manual for Selecting Sampling Techniques in Research. Retrieved from https://mpra.ub.uni-muenchen.de/70218/.

Aydin, B. (2001). A study of sources of foreign language classroom anxiety in speaking and writing classes (Unpublished doctoral dissertation). Anadolu University, Eskisehir.

Balemir, H. S. (2009). The Sources of Foreign Language Speaking Anxiety and the Relationship Between Proficiency Level and Degree of Foreign Language Speaking Anxiety (Unpublished master's thesis). Bilkent University Ankara.

Batumlu, Z. D., \& Erden, M. (2007). Yıldız Teknik Üniversitesi Yabancı Diller Yüksek Okulu hazırlık öğrencilerinin yabancı dil kaygıları ile İngilizce başarıları arasındaki ilişki. Eğitimde Kuram ve Uygulama, 3(1), 24-38.

Brown, A. L. (1987). Metacognition, executive control, self-regulation and other more mysterious mechanisms. In F. E. Weinert, \& R. H. Kluwe (Eds.), Metacognition, motivation and understanding (pp. 65-116). Hillside, New Jersey: Lawrence Erlbaum Associates.

Brown, H. D. (1994). Principles of language learning and teaching. New Jersey: Prentice Hall Regents.

Cagatay, S. (2015). Examining EFL students' foreign language speaking anxiety: The case at a Turkish state $\begin{array}{llllll}\text { University. } \quad \text { Procedia } & - & \text { Social Behavioral Sciences } & \text { 199, } 656 .\end{array}$ https://doi.org/10.1016/j.sbspro.2015.07.594

Carter, R., \& Nunan, D. (2002). The Cambridge guide to teaching English to speakers of other languages. Cambridge: Cambridge University Press.

Creswell, J. W. (2014). Research Design, Qualitative, Quantitative and Mixed Methods Approaches (4th ed.). Thousand Oaks, CA: Sage.

Dalkılıç, N. (2001). An investigation into the role of anxiety on students' success in second language learning (Unpublished doctoral dissertation). Çukurova University.

Fielding, M. (2007). Jean Rudduck (1937-2007). Carving a new order of experience: A preliminary appreciation of the work of Jean Rudduck in the field of students' voice. Educational Action Research, 15(3). https://doi.org/10.1080/09650790701514234

Hismanoglu, M. (2013). Foreign language anxiety of English language teacher candidates: A sample from Turkey. Procedia - Social Behavioral Sciences 93, 930-937. https://doi.org/10.1016/j.sbspro.2013.09.306

Horwitz, E. K., Horwitz, B. M., \& Cope, J. (1986). Foreign language classroom anxiety. The Modern Language Journal, 70(2), 125-132. https://doi.org/10.1111/j.1540-4781.1986.tb05256.x

Horwitz, E. K., Horwitz, B. M., \& Cope, J. A. (1991). Foreign language classroom anxiety. In E. K. Horwitz, \& D. J. Young (Eds.), Language anxiety: From theory and research to classroom implication (pp. 27-36). Englewood Cliffs, New Jersey: Prentice Hall.

Huang, H. (2004). The relationship between learning motivation and speaking anxiety among EFL non-English major freshmen in Taiwan (Unpublished master's thesis). Chaoyang University of Technology.

Karatas, H., Alci, B., Bademcioglu, M., \& Ergin, A. (2016). An Investigation into University Students' Foreign Language Speaking Anxiety. Procedia - Social behavioral Sciences, 232, 382-388. https://doi.org/10.1016/j.sbspro.2016.10.053

Kayaoglu, M. N., \& Saglamel, H. (2013). Students' perceptions of language anxiety in speaking classes. Tarih Kültür ve Sanat Arasturmalari Dergisi, 2(2), 142-160.

Lin, L. C. (2013). Measuring adult learners' foreign language anxiety, motivational factors and achievement expectations: A comparative study between Chinese as a second-language students and English as a second-language students. Cleveland State University. 
Llinas, M. M., \& Garau, J. M. (2009). Effects of language anxiety on three proficiency-level courses of Spanish as a foreign language. Foreign Language Annals, 42(1), 94-111. https://doi.org/10.1111/j.1944-9720.2009.01010.x

Mak, B. (2011). An exploration of speaking-in-class anxiety with Chinese ESL learners. System, 39, 202-214. https://doi.org/10.1016/j.system.2011.04.002

Mccroskey, J. C., \& Anderson, J. (1976). The relationship between academic achievement and communication apprehension among college students. Paper presented at Annual Convention of the International Communication Association, Portland. https://doi.org/10.1111/j.1468-2958.1976.tb00506.x

Mehar Singh, M. K., \& Chuah, J. S. C. (2012). Manufacturing industry employers' perception of graduates' English language skills proficiency. International Journal of Applied Linguistics \& English Literature, 1(4), 114-124. https://doi.org/10.7575/ijalel.v.1n.4p.114

Ministry of Higher Education, Malaysia. (2010). The National Education System. Retrieved from http://www.portal.mohe.gov.my/portal/page/portal/ExtPortal/Agencies/Study_in_Malaysia/National_Educat ion_System

Namsang, T. (2011). English language anxiety among Thai undergraduate students: A study at Dhonburi Rajabhat University (Unpublished master's thesis). Thammasat University, Thailand.

Nur Afiqah Ab. Latif (2015). A study on English language anxiety among adult learners in Universiti Teknologi Malaysia (UTM). Procedia - Social Behavioral Sciences, 208, 223-232. https://doi.org/10.1016/j.sbspro.2015.11.198

Öztürk, G., \& Gürbüz, N. (2013). The impact of gender on foreign language speaking anxiety and motivation. Procedia - Social and Behavioral Sciences, 70, 654-665. https://doi.org/10.1016/j.sbspro.2013.01.106

Rokiah @ Rozita Ahmad. (2012). Transformation of language of teaching and learning policy. Procedia - Social and Behavioral Sciences, 59, 685-691. https://doi.org/10.1016/j.sbspro.2012.09.331

Saltan, F. (2003). EFL speaking anxiety: How do students and teachers perceive it? (Unpublished master's thesis). METU, Ankara

Subaşi, G. (2010). What are the main sources of Turkish EFL students' anxiety in oral practice? Turkish Online Journal of Qualitative Inquiry, 1(2), 29-49.

Suleimenova, Z. (2013). Speaking anxiety in a foreign language classroom in Kazakhstan. Procedia - Social Behavioral Sciences 93, 1860-1868. https://doi.org/10.1016/j.sbspro.2013.10.131

Tanveer, M. (2007). Investigation of the factors that cause language anxiety for ESL/EFL learners in learning speaking skills and the influence it casts on communication in the target language (Unpublished master's thesis). University of Glasgow.

Tercan, G., \& Dikilitas, K. (2015). EFL students' speaking anxiety: A case from tertiary level students. International Association of Research in Foreign Language Education and Applied Linguistic ELT Research Journal, 4(1), 16-27.

Wilson, S. T. J. (2006). Anxiety in learning English as a foreign language: Its associations with student variables, with oral proficiency, and with performance on an oral test (Unpublished doctoral dissertation). Universidad de Granada.

Wu, \& Lin. (2014). Anxiety about speaking a foreign language as a mediator of the relation between motivation and willingness to communicate. Perceptual and Motor Skills, 119(3), 785-798. https://doi.org/10.2466/22.PMS.119c32z7

\section{Copyrights}

Copyright for this article is retained by the author(s), with first publication rights granted to the journal.

This is an open-access article distributed under the terms and conditions of the Creative Commons Attribution license (http://creativecommons.org/licenses/by/4.0/). 